\title{
3-(2-Chloropropyl amide)-4-methoxy-N- phenylbenzamide inhibits expression of HPV oncogenes in human cervical cancer cell
}

Fang Han ${ }^{1}$, Yanping $\mathrm{Li}^{1}$, Qiaoni Lu', Linlin Ma ${ }^{1,3}$, Huiqiang Wang ${ }^{1}$, Jiandong Jiang ${ }^{1,2}$, Zhuorong $\mathrm{Li}^{\mathrm{i}^{*}}$ and Yuhuan $\mathrm{Li}^{1 *}$

\begin{abstract}
Background: Human papillomaviruses (HPVs) are the primary causative agents for cervical cancer, and HPV oncoproteins E6 and E7 are known to be the main reason for the onset and maintenance of the malignancies. Therefore, inhibition of viral E6 and E7 oncoproteins expression represents a viable strategy to cervical cancer therapies. This study is to evaluate the antiviral effect of a novel N-Phenylbenzamide derivative, 3-(2-Chloropropyl amide)-4-methoxy-N-phenylbenzamide (L17), against HPV16 in vitro and identify its associated mechanism of action in cervical cancer cells.

Methods: The cytotoxic effect of L17 was assessed by MTT assay. The mRNA and protein levels of E6 and E7 oncogenes were analyzed by quantitative real-time reverse transcription PCR (qRT-PCR) and Western blot, respectively. p53 and Rb protein levels were also detected by Western blot. The effect of L17 on cell cycle was analyzed by flow cytometry.

Results: The cytotoxic effect of $L 17$ was greater in cervical carcinoma cells than in normal cells. L17 significantly reduced the expression of HPV16 E6 and E7 mRNA and protein, at least partly by enhancing degradation of HPV16 E6 and E7 mRNA. Moreover, reduced expression of E6 and E7 induced by L17 resulted in the up-regulation of p53 and Rb expression, which subsequently induced CaSki cells arrest at $\mathrm{G}_{0} / \mathrm{G}_{1}$ phase.

Conclusions: L17 has antiviral activity through suppressing E6 and E7 oncogene expression and could inhibit CaSki cell proliferating by inducing cells arrest at $\mathrm{G}_{0} / \mathrm{G}_{1}$ phase at nontoxic concentration, implying that $L 17$ might be exploited as a candidate agent for HPV-associated cervical cancer prevention and treatment.
\end{abstract}

Keywords: Antiviral, 3-(2-Chloropropyl amide)-4-methoxy-N-phenylbenzamide, Human papillomavirus (HPV) type 16, Cervical carcinoma

\section{Background}

Cervical cancer is one of the leading causes of cancer death in female $[1,2]$. Approximately $99.7 \%$ of cervical cancers are caused by high-risk (HR) human papillomavirus (HPV), a small double-stranded DNA virus [3-6]. Although HPV vaccines have been shown to be effective, they only offer prophylactic protection against a minor

\footnotetext{
* Correspondence: l-z-r@263.net; yuhuanlibj@126.com

${ }^{1}$ Institute of Medicinal Biotechnology, Chinese Academy of Medical Science \& Peking Union Medical College, No 1, Tiantan Xili, Beijing 100050, People's Republic of China

Full list of author information is available at the end of the article
}

fraction of HPV serotypes, and have no therapeutic effect for existing HPV infections [7]. In addition, there is no approved antiviral drug for the treatment of HPV infection $[8,9]$. The current therapy relies on nonspecific removal of infected tissue by often painful ablative procedures [8]. While this strategy may allow for elimination of signs and symptoms, recurrence rates are high due to subclinical virus infection of adjacent tissue [10]. What's more, for patients with cervical lesions, this strategy may have negative effects on the future reproductive outcomes [11]. These highlight an 
urgent need for development of efficacious virus-specific inhibitors to overcome HPV-associated cervical cancer.

Two viral oncoproteins E6 and E7 are the main reasons for the development of cervical cancer through binding to two tumor suppressor proteins, p53 and Rb, and neutralizing their functions $[12,13]$. E6 protein can facilitate tumor suppressor protein p53 degradation via the ubiquitin proteolytic pathway, which shortens the half-life of p53 and reduces its concentration, leading to the overrides at the $G_{1} / S$ and $G_{2} / M$ checkpoints $[14,15]$. This is the major cause of chromosomal instability and thus leads to the mutation of the HPV-positive cells. Similarly, E7 oncoprotein induces the ubiquitin-mediated proteolysis, and disrupts its association with the E2F family of transcription factors via interacting with the tumor suppressor protein $\mathrm{Rb}$, which subsequently activates genes associated with cell cycle progression [16, 17]. Therefore, inhibition of viral E6 and E7 oncoprotein expression represents a viable strategy that might restore growth control in tumor cells or sensitize cells to cancer therapies.

In our screening for drug candidates exhibiting inhibitory activity against HPV, we found that a novel N-Phenylbenzamide derivative, 3-(2-Chloropropyl amide)4-methoxy-N-phenylbenzamide, named L17, was active in inhibiting the expression of HPV oncoproteins E6 and E7. This is the first report of the anti-HPV activity of the Nphenylbenzamide derivative, to the best of our knowledge. The main objective of the present study is to evaluate the antiviral effect of L17 against HPV16 in vitro and identify its associated mechanism of action in cervical cancer cells.

\section{Methods}

Drug

L17 (HPLC>98\%) was synthesized in Chinese Academy of Medical Sciences and Peking Union Medical College and its chemical structure is shown in Fig. 1a. The compound was dissolved in Dimethyl sulfoxide (DMSO) at $100 \mathrm{mg} / \mathrm{ml}$ as a stock solution and further diluted in culture medium prior to use.

\section{Cell culture}

The CaSki (human cervical cancer cells, HPV 16 positive), HeLa (human cervical cancer cells, HPV 18 positive), C33A (human cervical cancer cells, HPV negative), $\mathrm{HaCaT}$ (Human keratinocyte cells, HPV negative) and the MRC-5 (human lung fibroblast cells, HPV negative) were obtained from American Type Culture Collection (ATCC). CaSki cells were cultured in RPMI 1640 media (Invitrogen, Carlsbad, CA, USA), HaCaT cells were cultured in Dulbecco's Modified Eagle Medium (DMEM, Invitrogen); C-33A, HeLa and MRC-5 cells were cultured in minimum essential medium (MEM, Invitrogen), respectively, containing 10\% Fetal Bovine Serum (Gibco, Grand Island, NY, USA), $100 \mathrm{U} / \mathrm{ml}$ penicillin G and $100 \mathrm{mg} / \mathrm{ml}$ streptomycin [18]. All cells were incubated in humidified atmosphere containing $5 \% \mathrm{CO}_{2}$ at $37{ }^{\circ} \mathrm{C}$.

\section{Cytotoxicity assay}

The cytotoxic effects of L17 on CaSki, HeLa, C-33A, $\mathrm{HaCaT}$ and MRC-5 cells were determined with the 3-(4,5dimethylthiazole-2-yl)-2,5-biphenyl tetrazolium bromide (MTT, Promega, Madison, WI, USA) [19]. Briefly, CaSki

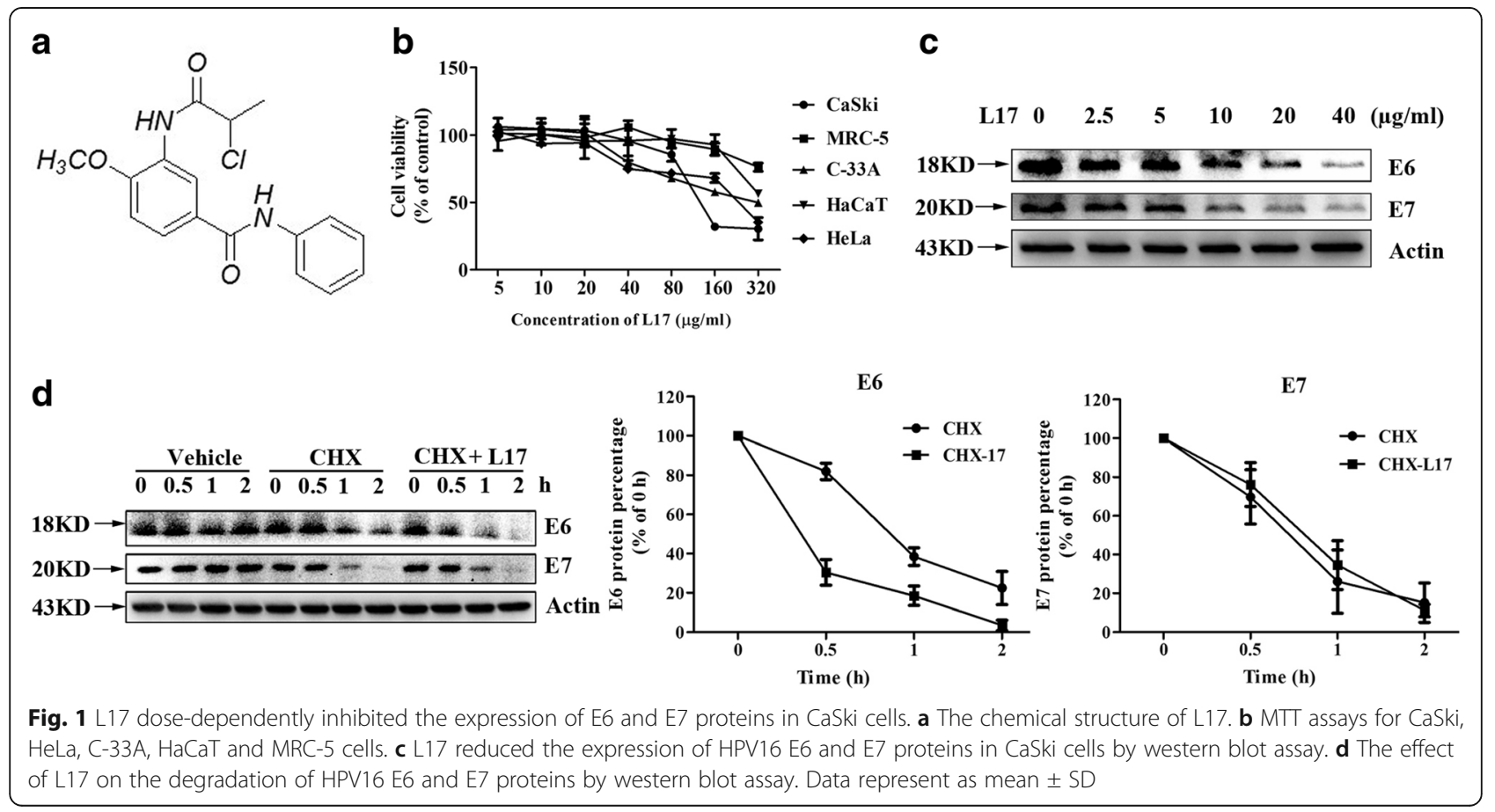


cells $\left(1 \times 10^{4}\right.$ per well $) \mathrm{HeLa}\left(2 \times 10^{4}\right.$ per well $)$, C-33A $\left(2 \times 10^{4}\right.$ per well), $\mathrm{HaCaT}\left(1.5 \times 10^{4}\right.$ per well $)$ and MRC-5 cells $\left(4.5 \times 10^{4}\right.$ per well) were seeded into 96-well culture plates and incubated for $12 \mathrm{~h}$. Then, different concentrations of L17 were applied in duplicate and incubated for $48 \mathrm{~h} .20 \mu \mathrm{l} \mathrm{MTT}(5 \mathrm{mg} / \mathrm{ml})$ was added to each well and incubated for another $4 \mathrm{~h}$, followed by solubilization in $150 \mu \mathrm{l}$ DMSO (Promega) and spectrophotometric measurement at $490 \mathrm{~nm}$ on Enspire (Perkin Elmer, Waltham, MA, USA). The maximum non-toxic concentration was defined as the concentration that cell survival rate is greater than 90\% (survival rate = absorbance of test group/absorbance of untreated controls).

\section{Quantitative real-time reverse transcription PCR (qRT-PCR) analysis of HPV16 E6 and E7 transcripts}

CaSki cells $\left(6 \times 10^{5}\right.$ per well $)$ were seeded into 6-well culture plates and incubated for $12 \mathrm{~h}$. Then, various concentrations of L17 were applied in duplicate and incubated for 12, 24, 36 and $48 \mathrm{~h}$. Total cellular RNA was extracted with RNeasy Mini kit (Qia-gen, Germantown, MD, USA) according to the manufacturer's protocol. The one-step quantitative RT-PCR (qRT-PCR) was conducted with the ABI 7500 Fast RT-PCR system (Applied Biosystems, Foster City, CA, USA) using SuperScript III Platinum SYBR Green One-step RT-PCR Kit (Invitrogen, Carlsbad, California, USA) with the following procedures: $50{ }^{\circ} \mathrm{C}$ for $3 \mathrm{~min}, 95{ }^{\circ} \mathrm{C}$ for $15 \mathrm{~min}$, followed by 40 cycles of $95{ }^{\circ} \mathrm{C}$ for $15 \mathrm{~s}, 60{ }^{\circ} \mathrm{C}$ for 30s [20]. The mRNA expression of HPV16 E6 was determined using primers (F: 5' -CTGCAATGTTTCAGGACCCA-3, R: 5' TCATGTATAGTTGTGCAGCTCTGT-3') targeting HP V-16 E6 open-reading frame. The mRNA expression of HPV16 E7 was determined using primers (F: 5'-GAGGA GGAGGATGAAATAGATGGT-3',R: 5' -CACTTGCAAC AAAACGTT ACAATATTG-3') targeting HPV-16 E7 open-reading frame. $\beta$-actin was determined using primers (F: 5' - CCAACCGCGAGAAGATGA-3', R: 5' CCAGAGGCGTACAGGGATAG - $3^{\prime}$ ). The $\Delta \Delta$ Ct method was used to represent mRNA fold change [21].

\section{Western blot analysis}

CaSki cells $\left(6 \times 10^{5}\right.$ per well $)$ and MRC- 5 cells $\left(5 \times 10^{5}\right.$ per well) were seeded into 6-well culture plates and incubated for $12 \mathrm{~h}$. Then, various concentrations of L17 were applied in duplicate and incubated for $48 \mathrm{~h}$. After incubation, whole cell lysates of CaSki and MRC-5 cells were extracted with M-PER mammalian protein extraction reagent (Thermo Fisher Scientific, Waltham, MA, USA). Nuclear fractions of CaSki cells were isolated with NE-PER nuclear and cytoplasmic extraction kit (Beyotime Biotechnology, Shanghai, China). The protein concentrations were determined by the $\mathrm{BCA}$ reagents (Thermo Fisher Scientific). The samples, containing
$20 \mu \mathrm{g}$ protein, were boiled for $10 \mathrm{~min}$ to denature and resolved on $12 \%(w / v)$ sodium dodecyl sulfate polyacrylamide gel electrophoresis (SDS-PAGE) gels. Then the proteins were transferred to polyvinylidene fluoride (PVDF) membranes (Milli-pore, Billerica, MA, USA). Immunodetection was performed with HPV16-E6 antibody (1:500) (Santa Cruz, sc-460, mouse monoclonal antibody, Dallas, Texas, USA) [22], HPV16-E7 antibody (1:500) (Santa Cruz, sc-6981, mouse monoclonal antibody) [23], p53 antibody (1:1000) (BD Biosciences, San Diego, CA, USA), Rb antibody (1:1000) (BD Biosciences) and Histone H3 antibody (1:1000) (Cell Signaling Technology, Beverly, MA, USA), followed by incubation with HRP-conjugated antibody (1:5000) (Santa Cruz). $\beta$ actin (1:5000) (Cell Signaling Technology) was used as a normalization standard in whole cell lysate fractions. Histone $\mathrm{H} 3$ was used to normalize nuclear protein loading [20, 24].

\section{Measurement of stability of HPV16 E6 and E7 mRNAs}

RNA synthesis inhibitor actinomycin D (Sigma-Aldrich, St Louis, MO, USA) was used to determine the effect of L17 on the stability of HPV16 E6 and E7 mRNAs [25]. CaSki cells $\left(6 \times 10^{5}\right.$ per well $)$ grown in 6-well plates were treated with or without L17 $(40 \mu \mathrm{g} / \mathrm{ml})$ for $4 \mathrm{~h}$ and then $5 \mu \mathrm{g} / \mathrm{ml}$ actinomycin D was added to 6-well plates. Cells were harvested at $0,2,4,6$ and $8 \mathrm{~h}$ post-actinomycin $\mathrm{D}$ treatment. Total cellular RNA was isolated with RNeasy Mini kit and qRT-PCR analyses of HPV16 E6 and E7 transcript levels were performed. HPV16 E6 and E7 transcript levels before actinomycin $\mathrm{D}$ treatment were determined as baselines in the experiment. Since mRNA degradation generally obeys first-order process, the slope for the correlation of E6, E7 mRNA level and time is the degradation constant $\mathrm{K}_{\mathrm{d}}\left(\ln \mathrm{C}=\ln \mathrm{C}_{0}-\mathrm{K}_{\mathrm{d}} \mathrm{t}\right.$, where $\mathrm{C}_{0}$ is the mRNA concentration at time zero) and the half-life of E6 and E7 mRNA was equal to $0.693 / \mathrm{k}_{\mathrm{d}}$ according to previously described method [25-28].

\section{Measurement of HPV16 E6 and E7 protein stability} Translation inhibitor cyclohexamide (CHX, SigmaAldrich, USA) was used to determine the effect of L17 on the stability of HPV16 oncoproteins E6 and E7 $[25,29]$. CaSki cells $\left(6 \times 10^{5}\right.$ per well $)$ were treated with L17 $(40 \mu \mathrm{g} / \mathrm{ml})$ in the presence or absence of CHX $(50 \mu \mathrm{g} / \mathrm{ml})$. Cells were harvested at 0, 0.5, 1 and $2 \mathrm{~h}$ after CHX treatment, and then cell lysates were extracted for Western blot analysis. In all these experiments, HPV16 E6 and E7 protein levels before CHX treatment were determined as baseline.

\section{Cell cycle analysis by flow cytometry}

Flow cytometry analysis was performed to demonstrate the effect of L17 on cell cycle progression. CaSki cells 
$\left(4 \times 10^{5}\right.$ per well $)$ and MRC- 5 cells $\left(4.5 \times 10^{5}\right.$ per well $)$ cells were plated into 6-well culture plates and incubated for $12 \mathrm{~h}$. Then, various concentrations of L17 were applied in duplicate and incubated for $48 \mathrm{~h}$. Then the cells were harvested and fixed in $70 \%$ ethanol at $4{ }^{\circ} \mathrm{C}$ for $12 \mathrm{~h}$. Before flow cytometry analysis, cells were stained with $1 \mathrm{ml}$ of PI $(15 \mathrm{mg} / \mathrm{ml})$ containing RNase $(2.5 \mathrm{mg} /$ $\mathrm{ml}$ ) (Beyotime Biotechnology). DNA content was determined by a Coulter EPICS XL/XL-MCL Flow Cytometry System (Coulter Corp, Brea, California, USA) and the proportion of cells in a particular phase of cell cycle was determined by ModFitLT software.

\section{Statistical analyses}

All results were expressed as mean \pm SD of data obtained from at least triplicate experiments using SPSS software. Statistical analysis was performed by using unpaired, two tailed Student's t-test. All comparisons were made relative to controls and $p<0.05$ was considered statistically significant.

\section{Results}

\section{L17 inhibited the expression of E6 and E7 proteins in}

\section{Caski cells}

The chemical structure of L17 is shown in Fig. 1a. We first studied its effects on the viability of CaSki (human cervical cancer cells, HPV 16 positive), HeLa (human cervical cancer cells, HPV 18 positive), C-33A (human cervical cancer cells, HPV negative), HaCaT (Human keratinocyte cells, HPV negative) and the MRC-5 (human lung fibroblast cells, HPV negative). The results showed that the maximum non-toxic concentration of L17 in CaSki, HeLa, C-33A, HaCaT and MRC-5 were 40, 20, 20, 160 and $80 \mu \mathrm{g} / \mathrm{ml}$, respectively (Fig. 1b).

Next, we studied the effects of L17 on the expression of HPV oncoproteins E6 and E7, which are associated with the development of cervical cancer. Our results showed that L17 down-regulated the expression of HPV E6 and E7 proteins in a dose-dependent manner in CaSki cells (Fig. 1c).

In order to determine how L17 decreased the level of HPV E6 and E7 proteins, we studied the effect of L17 on the stability of E6 and E7 proteins by using cyclohexamide (CHX), a potent translation inhibitor. Decreased stability of E6 protein was observed in presence of L17, whereas stability of E7 protein largely remained unaltered (Fig. 1d).

\section{L17 enhanced degradation of E6 and E7 mRNAs}

To examine the effect of L17 on the expression of HPV16 E6 and E7 mRNAs, CaSki cells treated with or without L17 were analyzed by qRT-PCR assay. The results showed that L17 decreased the expression of HPV16 E6 mRNA (Fig. 2a Left) and E7 mRNA (Fig. 2a Right) in a time-dependent and dose-dependent manner.

In order to determine how L17 decreased the HPV16 E6 and E7 mRNA expression, we carried out experiments with actinomycin $\mathrm{D}$, a potent transcription inhibitor. We observed that compound L17 reduced the transcript half-life time from approximately $7.0 \mathrm{~h}$ to $3.7 \mathrm{~h}$ for E6 (Fig. 2b Left) and from $5.3 \mathrm{~h}$ to $3.3 \mathrm{~h}$ for E7 (Fig. 2b Right), respectively.
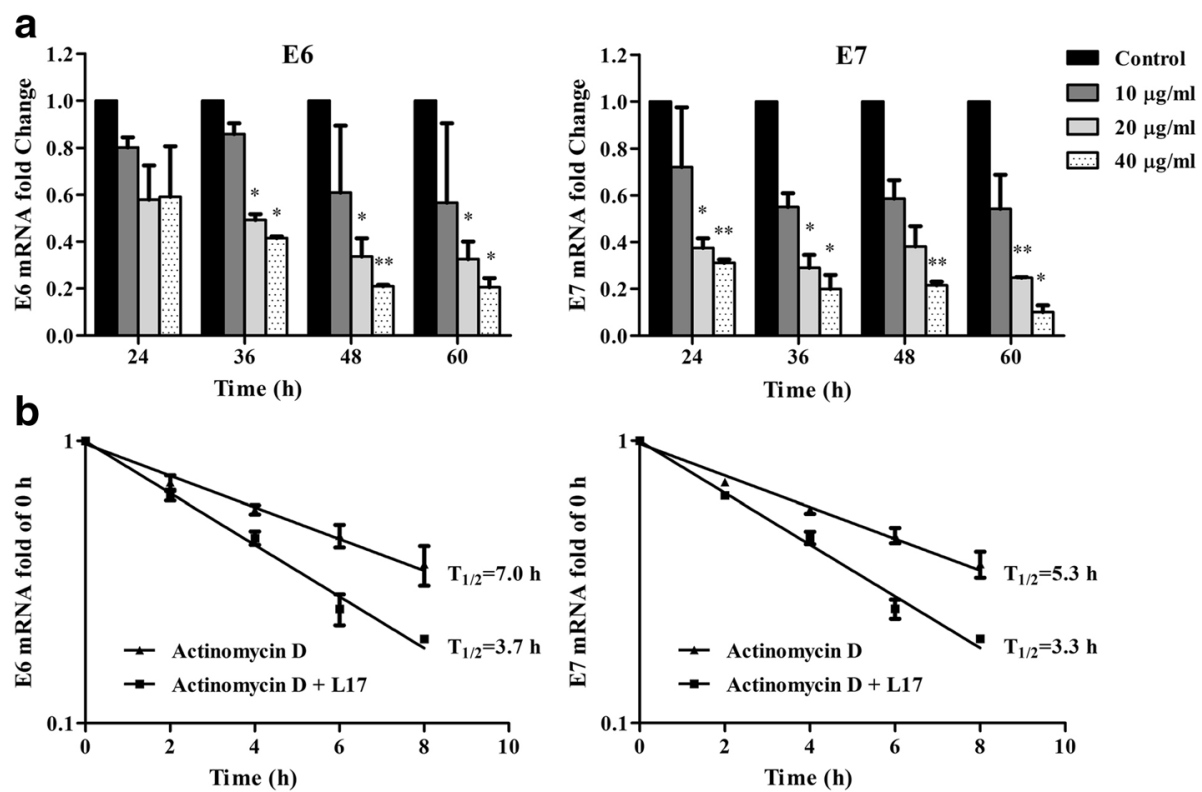

Fig. 2 L17 enhanced the degradation of E6 and E7 mRNA. a L17 reduced the expression of E6 and E7 mRNA of CaSki cells by one-step qRT-PCR assay. ${ }^{*} P<0.05 ;{ }^{*} P<0.01$. b L17 enhenced the degradation of HPV16 E6 and E7 mRNA by one-step qRT-PCR assay 
L17 up-regulated p53 and Rb expression in CaSki cells A number of genetic and biochemical studies have shown that $\mathrm{p} 53$ and $\mathrm{Rb}$ are the most important tumor suppressor proteins in keeping cells from immortalization and transformation [17, 30]. HPV oncoproteins E6 and E7 are known to cause the down-regulation of tumor suppressor proteins p53 and $\mathrm{Rb}$, which is linked to the malignant proliferation of cells [13]. We thus examined the effect of L17 on the expression of p53 and Rb. The results demonstrated that L17 dose-dependently up-regulated p53 and $\mathrm{Rb}$ protein expressions in HPV-positive CaSki cells (Fig. 3a). Considering the fact that p53mediated cell proliferation inhibition depends on its localization in the nucleus [31], it is necessary to examine the effect of L17 on p53 protein level in the nucleus of CaSki cells. We observed that L17 does-dependently increased p53 levels in the nucleus (Fig. 3a), which suggested that p53 exhibited a functional activation in the HPV-positive CaSki cells treated with L17. Interestingly, we found that L17 did not increase p53 and Rb proteins level in HPV-negtive MRC-5 cells (Fig. 3b). These results suggest that reduced expression of E6 and E7 is the key contributor to L17mediated up-regulation of p53 and Rb.

\section{The effect of L17 on cell cycle progression}

It has been shown that p53 and Rb played pivotal roles in the negative control of cell cycle progress. Next, we thus performed flow cytometry analysis of PI-stained cells to demonstrate the effect of L17 on cell cycle progression. In line with the increase of p53 and Rb expression in CaSki cells, our results revealed that L17 induced

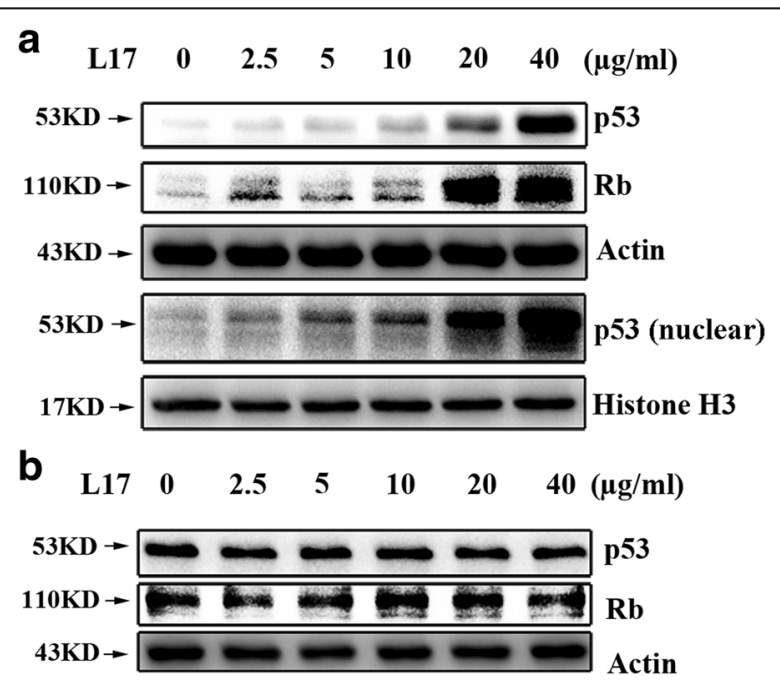

Fig. 3 The effect of $\mathrm{L} 17$ on the expression of $\mathrm{p} 53$ and $\mathrm{Rb}$ proteins. a $L 17$ up- regulated the expression of total p53 and Rb proteins and p53 in nucleus of CaSki cells by Western blot assay. $\mathbf{b}$ L17 did not effect the expression of p53 and Rb proteins of MRC- 5 cells by Western blot assay
CaSki cells arrest at $G_{0} / G_{1}$ phase in a dose-dependent manner (Fig. 4a). Meanwhile, we didn't observe obvious change of cell cycle in MRC-5 (Fig. 4b) treated with L17, which is in agreement with the finding that L17 had no effect on the levels of p53 and Rb in normal cells.

\section{Discussion}

In our previous study, we have shown that compounds of phenyl benzamide exerted a potent inhibitory action against influenza, EV71 and HCV [32-34]. Herein, we showed for the first time that L17, a novel derivative of phenyl benzamide, exerted a potent inhibitory action against HPV in CaSki cells. Given that persistent infection with high-risk HPVs is the major contributor to cervical cancer. Therefore, this study suggests that L17 might be a potential drug candidate or adjuvant to treat cervical cancer.

It is well established that the HPV oncoproteins E6 and E7 are the main contributors to cervical cancer. Our study demonstrated that L17 dose-dependently inhibited the expression of HPV E6 and E7 proteins in CaSki cells, which confirmed that L17 might have potential inhibitory activity against cervical cancer associated with HPV. Further research found that L17 could significantly decrease the stability of HPV16 E6, E7 mRNA and E6 protein, whereas the stability of E7 protein largely remained unaltered. The mechanisms underlying differential stability of E6 and E7 mRNA are still not understood in this study. It is known that the stability of mRNA is related to miRNA-mediated mRNA degradation, RNA binding proteins and the cell biological state [35-38]. Thus, we speculated that L17-mediated degradation of HPV mRNA might be associated with the changed expression of particular miRNAs targeting E6 and E7 mRNA. However, the exact reason for the decreased stability of E6 and E7 mRNA and protein needs further study.

It is reported that abrogating E6 and E7 function in neoplastic cells by targeting gene expression or proteinprotein interaction could reactivate p53 and pRb expression, with subsequent restore cell growth control which includes cell cycle arrest and apoptosis [14-17]. In our study, we observed that L17 does-dependently increased the expression of $\mathrm{p} 53$ and $\mathrm{Rb}$ tumor suppressor proteins in the HPV16 positive cervical cancer cell line CaSki. At the same time, the tumor suppressor protein levels in the HPV negative cell lines MRC-5 largely remained unaltered. This suggests that L17 does not directly change p53 and $\mathrm{Rb}$ expression, and the up-regulation in CaSki is caused by the down-regulation of E6 and E7. The increased nuclear location of p53 in CaSki treated with L17 suggested that p53 had a functional activation. In addition, we found that L17 does-dependently induced $\mathrm{G}_{0} / \mathrm{G}_{1}$ phase arrest in CaSki cells, while had no effect on the cell cycle of MRC-5, which implies that the cell cycle 


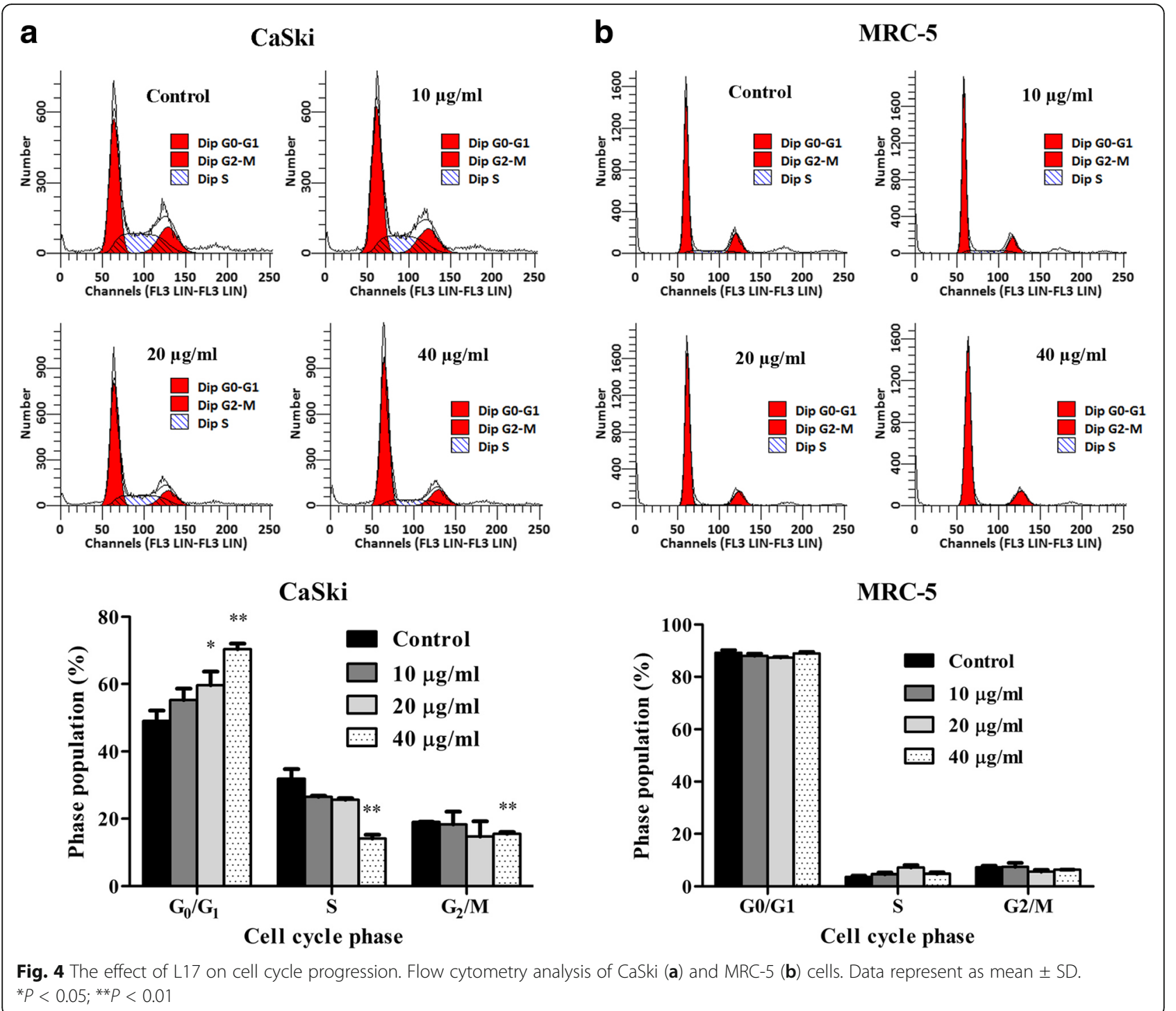

arrest in CaSki by $\mathrm{L} 17$ is linked to p53 and $\mathrm{Rb}$ up-regulation. In spite of the restoration of p53 function, we did not observe obvious apoptosis in the experiment, which is at odds with other published observations [8, 31]. This probably links to the hypothesis that although L17 could repress the expression of E7 protein, the level of E7 protein in cells probably remains high enough to drive mitotic signals to block the p53-dependent apoptosis.

Human papillomaviruses (HPVs) are the primary causative agents for cervical cancer, and HPV oncoproteins E6 and E7 are known to be the main reason for the onset and maintenance of the malignancies. Our study suggested that L17 had potential action in preventing cervical cancer by reducing the expression of HPV16 E6 and E7 at both the mRNA and protein levels. Importantly, treatment with L17 rescued high levels of p53 and $\mathrm{Rb}$ tumoursuppressor proteins in HPV16-positive cervical cells, and then induced the cell cycle arrest at $\mathrm{G}_{0} / \mathrm{G}_{1}$ phase. Of note, L17 had no effect on the expression of p53 and $\mathrm{Rb}$ and cell cycle in HPV-negative MRC-5. This suggested that L17 did not interfere with the proliferation of normal cells. Compared to direct anticancer drugs, L17 thus reveals a potential advantage of hypotoxicity against normal cell. However, it should be also noted that the lack of apoptosis induction might compromise the ability of L17 inhibition of growth in HPV positive cells.

\section{Conclusion}

In this study, we found that a compound L17 has antiviral activity through suppressing E6 and E7 oncogene expression and might be exploited as a candidate agent for HPVassociated cervical cancer prevention and treatment. 


\section{Abbreviations}

CHX: Cyclohexamide; HPVs: Human papillomaviruses; HR: High-risk; L17: 3-(2Chloropropylamide)-4-methoxy-N- phenylbenzamide; MTT: 3-(4,5-dimethylthiazole2-yl)-2,5-biphenyl tetrazolium bromide; PVDF: Polyvinylidene fluoride; qRTPCR: quantitative real-time reverse transcription PCR; SDS-PAGE: Sodium dodecyl sulfate polyacrylamide gel electrophoresis

\section{Acknowledgements}

Not applicable.

\section{Funding}

The work was supported by the Science Fund for Creative Research Groups of the National Natural Science Foundation of China (Grant 81,321,004). The work was also supported by the National Science and Technology Major Project of the Ministry of Science and Technology of China (2012ZX09301002-001-015) and CAMS Initiative for Innovative Medicine (CAMS-12M-1-010).

\section{Availability of data and materials}

The datasets supporting the conclusions of this article are included within the article.

\section{Authors' contributions}

FH and QNL designed and performed experiments, analyzed the data, and wrote the manuscript. YPL synthesised and provided the 3-(2-Chloropropyl amide)-4methoxy-N-phenylbenzamide (L17) compound. LLM and HQW provided suggestions on coordinated the experimental design and helped to edit the manuscript. JDJ contributed to research design. YHL and ZRL contributed to research design, research data, and preparation of the manuscript. All authors read and approved the final manuscript.

\section{Ethics approval and consent to participate}

Not applicable.

\section{Consent for publication}

Not applicable.

\section{Competing interests}

The authors declare that they have no competing interests.

\section{Publisher's Note}

Springer Nature remains neutral with regard to jurisdictional claims in published maps and institutional affiliations.

\section{Author details}

${ }^{1}$ Institute of Medicinal Biotechnology, Chinese Academy of Medical Science \& Peking Union Medical College, No 1, Tiantan Xili, Beijing 100050, People's Republic of China. ${ }^{2}$ Institute of Materia Medica, Chinese Academy of Medical Sciences and Peking Union Medical College, No 1, Tiantan Xili, Beijing 100050, China. ${ }^{3}$ Key Laboratory of Molecular Imaging of Shanghai Education Commission, Shanghai University of Medicine \& Health Sciences, No 279, Zhouzhugong Road, Shanghai 201318, People's Republic of China.

\section{Received: 16 February 2017 Accepted: 14 July 2017}

Published online: 28 July 2017

\section{References}

1. Schiffman M, Wentzensen N, Wacholder S, Kinney W, Gage JC, Castle PE. Human papillomavirus testing in the prevention of cervical cancer. J Natl Cancer Inst. 2011;103:368-83.

2. Jemal A, Bray F, Center MM, Ferlay J, Ward E, Forman D. Global cancer statistics. CA Cancer J Clin. 2011;61:69-90.

3. Bodily J, Laimins LA. Persistence of human papillomavirus infection: keys to malignant progression. Trends Microbiol. 2011;19:33-9.

4. Crow JM. HPV: the global burden. Nature. 2012;488:S2-3

5. Forman D, de Martel C, Lacey CJ, Soerjomataram I, Lortet-Tieulent J, Bruni L, Vignat J, Ferlay J, Bray F, Plummer M, Franceschi S. Global burden of human papillomavirus and related diseases. Vaccine. 2012:30(Suppl 5):F12-23.

6. Jimenez-Wences H, Peralta-Zaragoza O, Fernandez-Tilapa G. Human papilloma virus, DNA methylation and microRNA expression in cervical cancer (Review). Oncol Rep. 2014;31:2467-76.
7. Pogoda CS, Roden RB, Garcea RL. Immunizing against anogenital cancer: HPV vaccines. PLoS Pathog. 2016:12:e1005587.

8. Snoeck R. Papillomavirus and treatment. Antivir Res. 2006;71:181-91.

9. Hampson L, Martin-Hirsch P, Hampson IN. An overview of early investigational drugs for the treatment of human papilloma virus infection and associated dysplasia. Expert Opin Investig Drugs. 2015;24: 1529-37.

10. Phelps WC, Barnes JA, Lobe DC. Molecular targets for human papillomaviruses: prospects for antiviral therapy. Antivir Chem Chemother 1998;9:359-77.

11. Arbyn M, Kyrgiou M, Simoens C, Raifu AO, Koliopoulos G, Martin-Hirsch P, Prendiville W, Paraskevaidis E. Perinatal mortality and other severe adverse pregnancy outcomes associated with treatment of cervical intraepithelial neoplasia: meta-analysis. BMJ. 2008;337:a1284.

12. Moody CA, Laimins LA. Human papillomavirus oncoproteins: pathways to transformation. Nat Rev Cancer. 2010;10:550-60.

13. Narisawa-Saito M, Kiyono T. Basic mechanisms of high-risk human papillomavirus-induced carcinogenesis: roles of E6 and E7 proteins. Cancer Sci. 2007;98:1505-11.

14. Thomas M, Pim D, Banks L. The role of the E6-p53 interaction in the molecular pathogenesis of HPV. Oncogene. 1999;18:7690-700.

15. Jansen-Durr P. How viral oncogenes make the cell cycle. Trends Genet. 1996:12:270-5.

16. Munger K, Basile JR, Duensing S, Eichten A, Gonzalez SL, Grace M, Zacny VL. Biological activities and molecular targets of the human papillomavirus E7 oncoprotein. Oncogene. 2001;20:7888-98.

17. Accardi L, Dona MG, Mileo AM, Paggi MG, Federico A, Torreri P, Petrucci TC, Accardi R, Pim D, Tommasino M, et al. Retinoblastoma-independent antiproliferative activity of novel intracellular antibodies against the E7 oncoprotein in HPV 16-positive cells. BMC Cancer. 2011;11:17.

18. Maher DM, Bell MC, O'Donnell EA, Gupta BK, Jaggi M, Chauhan SC. Curcumin suppresses human papillomavirus oncoproteins, restores p53, Rb, and PTPN13 proteins and inhibits benzo[a]pyrene-induced upregulation of HPV E7. Mol Carcinog. 2011:50:47-57.

19. Sylvester PW. Optimization of the tetrazolium dye (MTT) colorimetric assay for cellular growth and viability. Methods Mol Biol. 2011;716:157-68.

20. Wang HQ, Meng S, Li ZR, Peng ZG, Han YX, Guo SS, Cui XL, Li YH, Jiang JD. The antiviral effect of 7-hydroxyisoflavone against Enterovirus 71 in vitro. J Asian Nat Prod Res. 2013;15:382-9.

21. Livak KJ, Schmittgen TD. Analysis of relative gene expression data using real-time quantitative PCR and the 2(-Delta Delta C(T)) Method. Methods. 2001;25:402-8.

22. Li W, Anderson RA. Star-PAP controls HPV E6 regulation of p53 and sensitizes cells to VP-16. Oncogene. 2014;33:928-32.

23. Fan X, Chen JJ. Role of Cdk1 in DNA damage-induced G1 checkpoint abrogation by the human papillomavirus E7 oncogene. Cell Cycle. 2014; 13:3249-59.

24. Cha MK, Lee DK, An HM, Lee SW, Shin SH, Kwon JH, Kim KJ, Ha NJ. Antiviral activity of Bifidobacterium adolescentis SPM1005-A on human papillomavirus type 16. BMC Med. 2012;10:72.

25. Munagala R, Kausar H, Munjal C, Gupta RC. Withaferin A induces p53dependent apoptosis by repression of HPV oncogenes and upregulation of tumor suppressor proteins in human cervical cancer cells. Carcinogenesis. 2011;32:1697-705

26. Ross J. mRNA stability in mammalian cells. Microbiol Rev. 1995:59:423-50.

27. Luczak MW, Jagodzinski PP. Apicidin down-regulates human papillomavirus type 16 E6 and E7 transcripts and proteins in SiHa cervical cancer cells. Cancer Lett. 2008;272:53-60.

28. Mellenthin M, Ellersiek U, Borger A, Baier M. Expression of the Arabidopsis sigma factor SIG5 is photoreceptor and photosynthesis controlled. Plants (Basel). 2014;3:359-91.

29. Jing K, Shin S, Jeong S, Kim S, Song KS, Park JH, Heo JY, Seo KS, Park SK, Kweon GR, et al. Docosahexaenoic acid induces the degradation of HPV E6/ E7 oncoproteins by activating the ubiquitin-proteasome system. Cell Death Dis. 2014;5:e1524.

30. Bossi G, Sacchi A. Restoration of wild-type p53 function in human cancer: relevance for tumor therapy. Head Neck. 2007;29:272-84.

31. Abdulkarim B, Sabri S, Deutsch E, Chagraoui H, Maggiorella L, Thierry J, Eschwege F, Vainchenker W, Chouaib S, Bourhis J. Antiviral agent Cidofovir restores p53 function and enhances the radiosensitivity in HPV-associated cancers. Oncogene. 2002;21:2334-46. 
32. Hao LH, Li YP, He WY, Wang HQ, Shan GZ, Jiang JD, Li YH, Li ZR. Synthesis and antiviral activity of substituted bisaryl amide compounds as novel influenza virus inhibitors. Eur J Med Chem. 2012;55:117-24.

33. Ji XY, Wang HQ, Hao LH, He WY, Gao RM, Li YP, Li YH, Jiang JD, Li ZR. Synthesis and antiviral activity of $\mathrm{N}$-phenylbenzamide derivatives, a novel class of enterovirus 71 inhibitors. Molecules. 2013;18:3630-40.

34. Jiang Z, Wang H, Li Y, Peng Z, Li Y, Li Z. Synthesis and antiviral activity of a series of novel $\mathrm{N}$-phenylbenzamide and $\mathrm{N}$-phenylacetophenone compounds as anti-HCV and anti-EV71 agents. Acta Pharm Sin B. 2015;5:201-9.

35. Hao S, Baltimore D. The stability of mRNA influences the temporal order of the induction of genes encoding inflammatory molecules. Nat Immunol. 2009;10:281-8.

36. Sharova LV, Sharov AA, Nedorezov T, Piao Y, Shaik N, Ko MS. Database for mRNA half-life of 19977 genes obtained by DNA microarray analysis of pluripotent and differentiating mouse embryonic stem cells. DNA Res. 2009; 16:45-58

37. Houseley J, Tollervey D. The many pathways of RNA degradation. Cell. 2009;136:763-76.

38. Hoen PA T, Hirsch M, de Meijer EJ, de Menezes RX, van Ommen GJ, den Dunnen JT. mRNA degradation controls differentiation state-dependent differences in transcript and splice variant abundance. Nucleic Acids Res. 2011:39:556-66

\section{Submit your next manuscript to BioMed Central} and we will help you at every step:

- We accept pre-submission inquiries

- Our selector tool helps you to find the most relevant journal

- We provide round the clock customer support

- Convenient online submission

- Thorough peer review

- Inclusion in PubMed and all major indexing services

- Maximum visibility for your research

Submit your manuscript at www.biomedcentral.com/submit 